\title{
Impoliteness in the Realization of Complaint Speech Acts: A Comparative Study of Iranian EFL Learners and Native English Speakers
}

\author{
Atefeh Nikoobin ${ }^{1} \&$ Mohsen Shahrokhi ${ }^{1}$ \\ ${ }^{1}$ English Department, Najafabad Branch, Islamic Azad University, Najafabad, Iran \\ Correspondence: Mohsen Shahrokhi, English Department, Najafabad Branch, Islamic Azad University, \\ Najafabad, Iran. E-mail: Shahrokhi1651@yahoo.com
}

Received: October 30, 2016 Accepted: November 14, 2016 Online Published: January 19, 2017

doi:10.5539/ijel.v7n2p32 URL: http://dx.doi.org/10.5539/ijel.v7n2p32

\begin{abstract}
This study was conducted to investigate the impolite complaint strategies that are used by Iranian EFL learners and native speakers in relation to social distance. This study also aimed at determining if there were significant differences among the strategies used by each group and if there was a significant difference between Iranian native speakers of English. To this end, 40 Iranian EFL learners and 20 Americans who were native speakers of English participated in this study. To make sure about the homogeneity of Iranian participants the Oxford Placement Test (OPT) was conducted. A questionnaire containing 12 different situations was designed by the researchers and was given to the participants to express their complaints for each situation. The results revealed that there were significant differences among the strategies used by each group; the most common strategy that was used by both groups of participants was positive impoliteness and the least common one was bald-on-record. Although the most and least common strategies used by both groups were the same, Iranians had a stronger tendency for using sarcasm in low social distance situations while natives had a stronger tendency for using bald-on-record in high social distance contexts. This study has implications for EFL curriculum designing in Iran and can make Iranian EFL instructors familiar with the importance of impoliteness as an indispensable part of language.
\end{abstract}

Keywords: impoliteness, speech Act, complaint, Iranian EFL learners, social distance

\section{Introduction}

\subsection{Background to the Study}

Impoliteness is an insolent manner that disregards accepted social usage (Lewis, 2003). According to Bousfield and Locher (2008, p. 3) "impoliteness is behaviour that is face-aggravating in a particular context". Impoliteness is also defined as "communicative strategies designed to attack face, and thereby cause social conflict and disharmony" (Culpeper, Bousfield, \& Wichmann, 2003, p. 1546). According to Culpeper (2005), impoliteness is not (a) incidental face-threat, (b) unintentional, (c) banter, and (d) bald-on record politeness.

Culpeper (1996) stated that there are different strategies for expressing impoliteness: bald-on record impoliteness, positive impoliteness, negative impoliteness, off-record impoliteness, and withhold politeness. Culpeper also categorized sarcasm or mock politeness as meta-strategy impoliteness. Bald-on record impoliteness is a direct, clear, unambiguous, and concise impolite speech in which face is not irrelevant or minimized. Positive impoliteness is the use of strategies employed to harm the addressee's positive face. Negative impoliteness is the use of strategies used to harm the addressee's negative face. Off-record impoliteness happens when the face-threatening act is done by means of an implicature as one attributable intention clearly prevails over any others. Withhold politeness is the nonexistence of politeness work where it is supposed to be existed. Sarcasm happens when the face-threatening act is done with the use of politeness strategies that are obviously artificial and the speaker means the opposite of what is said.

Impoliteness is quite relevant when the speech acts are performed. The theory of speech act was proposed by John Austin in 1962. A speech act is an utterance that serves a function in communication (Austin, 1962). According to Richards and Schmidt (2010), in speech act theory, utterances have locutionary and illocutionary acts. Locutionary act is the basic literal meaning of the utterance, which is conveyed by the particular words and 
structures, and illocutionary act is the intention of utterance, which is also called speaker's intention. In addition to locutionary and illocutionary acts, there is another act, which is perlocutionary act. Perlocutionary act is an act of speaking or writing which has an action as its aim but which in itself does not affect or constitute the action, for example persuading or convincing (Stevenson \& Waite, 2011).

Authentic English conversations are full of informal and impolite expressions that are used by native speakers in real interactions. English language teaching usually deals with the formal side of second language interaction such as making friends, relating experiences, and expressing likes/dislikes and usually ignores everyday communicative realities such as impoliteness, insolence, and discourteousness. Although impoliteness is neglected in EFL classrooms, it is possible to be experienced by L2 users in the target-language context or when interacting with other L2 users (Mugford, 2008).

Most foreign language learners rely on the structures of their first languages when they encounter a situation in the second language that is new and unfamiliar to them (Corder, 1987). Based on this premise, there is the possibility that EFL learners use their first language strategies when they encounter an impolite situation in English that can be totally different from strategies that are used by native speakers. Since impoliteness is a neglected area in EFL classrooms and EFL learners are not familiar enough with this form of language, teaching this kind of language in EFL classrooms and making EFL learners familiar with it, is imperative

\subsection{This Study}

According to Rogers (2004), informal language learning is unstructured, unpurposeful but is the most extensive and most important part of all the learning that all of us do in every day of our lives. On the contrary, formal language learning is structured, purposeful, and school based. In other words, informal language is acquired by daily activities not by regular education. Because of the nature of informal language, it is very difficult for EFL learners to learn it correctly and use it properly.

Having enough language input is necessary for acquiring any sort of language ability (Bahrani \& Sim, 2012). Since informal and impolite expressions are used by native English speakers in their daily informal conversations and these kinds of expressions are not covered by educational programs and English learning books, most EFL learners are not familiar enough with these kinds of expressions.

Mastery of politeness norms and rules can only be complete when impoliteness is also acquired. Most studies that have been done on the realm of impoliteness do not properly describe and predict how impoliteness can be used by speakers in extended, real-life interactions (Bousfield, 2008). Therefore, performing a study on how native and non-native speakers apply impoliteness strategies in the real world situations and interacting with one another is really felt necessary by Iranian EFL instructors and teachers including the researchers of the current study.

Social distance is the degree of acceptance or rejection of social intercourse between individuals belonging to diverse racial, ethnic, or class groups (Babcock \& Gove, 1993). The social distance between two different groups or communities influences communication between them, and may affect the way one group learns the language of another (Richards \& Schmidt, 2010). Social distance is conceptualized in three different ways. A) Affective social distance which focuses on affectivity. According to this approach, social distance is associated with the amount of sympathy the members of a group feel for another group. B) Normative social distance which refers to the commonly accepted and frequently consciously expressed standards about who should be regarded as an insider and who an outsider or foreigner. C) Interactive social distance which focuses on the frequency and intensity of interactions between two groups. The main idea here is that the more the members of two groups interact, the closer they are socially (Karakayali, 2009).

Since native English speakers and EFL learners have different perceptions of impoliteness expressions while performing speech acts and this field of study has not been investigated enough by EFL/ESL researchers, this study tries to investigate what impoliteness strategies are used by Iranian EFL learners in the realization of complaint speech acts. Moreover, this study is an attempt to determine the differences between Iranian EFL learners and native English speakers in using impoliteness strategies in the realization of complaint speech acts in relation to social distance as a contextual variable.

\subsection{Research Questions}

This study was an attempt to find answers to the following research questions:

$\mathrm{RQ}_{1}$. Is there any significant difference among impolite complaint strategies realized by Iranian EFL learners? 
$\mathrm{RQ}_{2}$. Does social distance affect the use of impolite complaint strategies realized by Iranian EFL learners?

$\mathrm{RQ}_{3}$. Is there any significant difference among the impolite strategies used by native English speakers?

$\mathrm{RQ}_{4}$. Does social distance significantly affect the use of impolite complaint strategies realized by native English speakers?

$\mathrm{RQ}_{5}$. Is there any significant difference between Iranian EFL learners and native English speakers in the frequency use of impolite complaint strategies?

$\mathrm{RQ}_{6}$ Why do Iranian EFL learners opt for a given impolite complaint strategy?

\subsection{Research Hypotheses}

The following research hypotheses were used for conducting this study:

$\mathrm{HO}_{1}$. There is no significant difference among impolite complaint strategies realized by Iranian EFL learners.

$\mathrm{HO}_{2}$. Social distance does not affect the use of impolite complaint strategies realized by Iranian EFL learners.

$\mathrm{HO}_{3}$. There is no significant difference among the impolite strategies used by native English speakers.

$\mathrm{HO}_{4}$. Social distance does not significantly affect the use of impolite complaint strategies realized by native English speakers.

$\mathrm{H}_{5}$. There is no significant difference between Iranian EFL learners and native English speakers in the frequency use of impolite complaint strategies.

\section{Methodology}

\subsection{Participants}

The participants of this study were 40 Iranian M.A. and B.A. students who studied English at Najafabad University, Isfahan, Iran, and 60 native English speakers who were university students in the United States. The ages of the Iranian participants were between 22 and 30. Iranian participants were selected from M.A. and B.A. students of TEFL. The participants were selected non-randomly from M.A. and B.A. students who were available and possible to be tested. The Oxford Placement Test (OPT) was conducted to identify that the participants were homogeneous and all participants' general English levels were upper intermediate. The OPT was used in this study to estimate the proficiency level of the Iranian EFL learners and to make sure that they were homogeneous. The placement test was administered to 80 Iranian participants and 40 of them with higher levels of proficiency were selected for the study.

\subsection{Instruments}

OPT, the Multiple Discourse-Completion Task (MDCT), and a structured interview were used in this study as instruments.

\subsubsection{OPT}

The OPT provides a reliable and efficient means for placing students properly at the beginning of a course for teachers (Allan, 2004). According to Allan (2004), the test has been calibrated against the levels system provided by the Common European Framework of Reference for Languages: Learning, Teaching, Assessment (commonly known as the CEF), which has been adopted by the Association of Language Testers in Europe (ALTE) as well as by governments and major institutions, including exam boards, throughout Europe. The OPTs can clearly and reliably identify any learner's CEE level (on the Al to C2 CEE scale) and also provide a score which will show where the learner within that band is, e.g., near the top of B1. They can also discriminate at levels above and below the CEF scale (Allan, 2004).

Each Oxford Placement Test Pack consists of two test pads containing enough copies of the Listening and Grammar Tests for students, the Teachers' Introduction, and a Key for the Tests. A cassette accompanies each Listening Test. The Oxford Placement Tests can be used with any number of students of English to ensure efficient, reliable, and accurate grading and placing of students into classes at all levels from pre-elementary to post-proficiency, encompassing the Common European Framework (CEF) levels Al to C2+. They will help institutions and individuals to decide on suitable teaching materials. They can also determine realistic learning objectives and examination targets for groups or individuals (Allan, 2004).

Each test is divided into two main sections (Listening Test and Grammar Test), each of 100 items. The first section is primarily a test of reading and listening skills, and of vocabulary size, in which the learner's 
performance is dependent on applying knowledge of the sound and writing systems of English and on the ability to make use of this knowledge at a task-speed well within the competence of a native speaker of English. The second section is a test of grammar, vocabulary, and reading skills, tested as far as possible in context. It involves a carefully selected range of items with facility values and discrimination indices designed to provide meaningful discrimination at each of the levels identified by the Common European Framework (Allan, 2004).

The test, which was used in the study, was designed for estimating the vocabulary and grammar skills of the participants. The test contained 60 multiple-choice questions, among which the first 40 questions were used for all participants and the last 20 questions were used for the advanced participants who could finish part 1 without problems. Since this test was a standard test, it had acceptable reliability and validity.

\subsubsection{Multiple Discourse-Completion Task (MDCT)}

A Multiple-choice Discourse Completion Task (MDCT) is a kind of task that encourages the participants to choose the best response among three, four, or five alternatives (Rezaei, 2010). While all MDCTs should share general characteristics, there is no singular definition that clearly explains what an MDCT item should look like in order to be referred to as such. The potential of MDCTs in language assessment has been explored in a variety of settings and with examinees of more than one ethnicity, language, and proficiency level (Setoguchi, 2008). MDCT item format differs across the context and purpose of the intended assessment in which they are being used, evolving and adapting to specific needs of various contexts of use (Jianda, 2007; Roever, 2006).

According to Ahn (2005), using an MDCT has some advantages and disadvantages. The advantages are (a) It is easy to administer, (b) Short time to conduct, (c) Easy to analyze students' performance, and (d) Not an issue of interrater reliability. The disadvantages are (a) Students may select the answers carelessly, (b) Hard to agree on the most appropriate answer among the native speakers, (c) Hard to measure students' pragmatic competence, (d) No actual language production but only recognition, (e) Difficult to find good distractors, and (f) Low reliability compared to other test types.

To calculate the reliability of the task, the Cronbach's Alpha was conducted for this purpose. In order to do this a pilot study was performed by selecting 10 of the questionnaires randomly. In order to evaluate the validity of the task, three experts who had Ph.D. degrees in TEFL were consulted to be sure about the validity of the task.

\subsubsection{Structured Interview}

Interview is defined as "a conversation between an investigator and an individual or a group of individuals in order to gather information" (Richards \& Schmidt, 2010, p. 298). Interviews are divided into depth interview, focused interview, guided interview, structured interview, and unstructured interview. A depth interview is a detailed interview which encompasses an extensive range of topics to obtain as much information as possible and to discover unknown variables that are introduced during the interview. A focused interview is an interview that explores a specific feature of an event or situation, especially with a group of individuals who have had similar experience of the event. Guided interview is an interview in which a set of questions that has been prepared in advance and that is used to guide and structure the interview is used by the interviewer. Structured interview is an interview in which the organization and procedure of the interview, as well as the topics to be asked about, the questions, and the order in which they will be presented, have all been determined in advance. An unstructured interview is a kind of interview which is investigative in nature with no fixed format (Richards \& Schmidt, 2010).

The reason of selecting a structured interview for this study was to understand why the participants choose the alternatives for each situation. The interview was designed to elicit the participants' ideas and reactions when they face different situations. The participants were interviewed orally, they were asked to express their reasons for choosing alternatives, and their voices were recorded to be transcribed later. After transcribing the participants' answers, the answers were analyzed to detect the participants' reasons for selecting the alternatives.

\subsection{Data Collection Procedure}

In the first step, the EFL learners were tested by the Oxford Placement Test (OPT) to estimate their proficiency levels and to make sure that they were rather homogeneous. After estimating the levels of the participants, the situations were piloted to 10 Iranian EFL learners. The Cronbach's Alpha was used for verifying the reliability. In order to make sure of the validity of the situations, three experts who had Ph.D. degrees in the field of TEFL were consulted and they were asked to check the situations and express their opinions about the validity of the situations based on grammar, vocabulary, and the appropriateness of the options in each situation. After being sure about the reliability and validity of the situations, they were given to all participants and they were asked to choose one of the alternatives when facing each one of these situations. 
After collecting the participants' data, 20 of the Iranian EFL participants were selected randomly and they were interviewed through the structured interview to explain their reasons for selecting the alternatives. Because only Iranian participants were available, they were chosen for performing the interview and the native participants were not interviewed because they were not available. The interviews were recorded digitally by a recording device and the recorded data were transcribed for content analysis. Ultimately, the researchers interpreted the participants' answers and the reasons based on them the answers were selected for analyzing the data and making conclusions. The questionnaires were sent to the native speakers through email. They were asked to choose one of the alternatives or expressed their opinions for each situation and email the questionnaire back to the researchers.

\subsection{Data Analysis Framework}

The following impolite strategies were adopted from Culpeper's (1996) impoliteness theory to analyze impolite complaints identified in the data.

- Bald on Record Impoliteness: This form of impoliteness happens when the face-threatening act is performed in a direct, clear, unambiguous, and concise way in circumstances where face is not irrelevant or minimized. Bald on record impoliteness is regarded as normally being used where there is much face at risk, and where there is a purpose on the part of the speaker to attack the face of the hearer and/or where the speaker does not have the power to (safely) utter an impolite utterance (Culpeper, 2005).

- Positive Impoliteness: The super strategy exists for the use of strategies designed to damage the addressee's positive face wants (Culpeper, 1996). These strategies include: a) ignore or snub the other, b) exclude the other from the activity, c) disassociate from the other, d) be disinterested, unconcerned, unsympathetic, e) use inappropriate identity markers, f) use obscure or secretive language, g) seek disagreement, h) make the other feel uncomfortable, i) use taboo words, and j) call the other names (Culpeper, 1996).

- Negative Impoliteness: Negative impoliteness is "The use of strategies designed to damage the addressee's negative face wants" (Culpeper, 2005, p. 41). The strategies include: a) Frighten, b) Condescend, scorn or ridicule, c) Invade the other's space, d) Explicitly associate H with negative aspect, e) Put H's indebtedness on record, and f) Hinder (Culpeper, 1996).

- Sarcasm: the FTA is performed with the use of politeness strategies that are obviously insincere, and thus remain surface realizations (Culpeper, 1996).

The strategies 'off-record impoliteness' and 'Withhold politeness' introduced by Culpeper (1996) were not used because they were not performative impolite strategies and were not applicable to data collected.

\section{Results}

In order to analyze the statistical data of this study, Statistical Package for the Social Sciences (SPSS) software Version 22 was used by the researchers. After gathering the elicited data, both descriptive and inferential statistics were used to analyze the collected data. Relevant statistics were used to figure out if there was a difference between Iranian EFL learners and native English speakers in using impoliteness strategies of complaint speech acts.

\subsection{Research Question One}

In order to answer the first research question, the analysis of data included the identification and classification of impolite complaint strategies according to data analysis framework of the study that was described above.

The results are tabulated and displayed based on the impolite complaint strategies namely, Bald on Record, Sarcasm, Positive Impoliteness, and Negative Impoliteness across all situations.

Table 1. Frequency and percentages of impolite complaints across all situations for Iranian EFL learners

\begin{tabular}{lllllllll}
\hline \multirow{2}{*}{ Situations } & \multicolumn{2}{l}{$\begin{array}{l}\text { Strategies } \\
\text { Bald on Record }\end{array}$} & \multicolumn{2}{l}{ Sarcasm } & \multicolumn{2}{c}{ Negative Impoliteness } & \multicolumn{2}{c}{ Positive Impoliteness } \\
\cline { 2 - 9 } & F & P (\%) & F & P (\%) & F & P (\%) & F & P (\%) \\
\hline S1 & 7 & 17.5 & 17 & 42.5 & 6 & 15.0 & 10 & 25.0 \\
S2 & 7 & 17.5 & 2 & 5.0 & 21 & 52.5 & 10 & 25.0 \\
S3 & 12 & 30.0 & 8 & 20.0 & 6 & 15.0 & 14 & 35.0 \\
S4 & 7 & 17.5 & 5 & 12.5 & 12 & 30.0 & 16 & 40.0 \\
S5 & 11 & 27.5 & 14 & 35.0 & 7 & 17.5 & 8 & 20.0 \\
S6 & 1 & 2.5 & 12 & 30.0 & 13 & 32.5 & 14 & 35.0 \\
\hline
\end{tabular}




\begin{tabular}{lllllllll}
\hline S7 & 1 & 2.5 & 11 & 27.5 & 9 & 22.5 & 19 & 47.5 \\
S8 & 4 & 10.0 & 11 & 27.5 & 1 & 2.5 & 24 & 60.0 \\
S9 & 5 & 12.5 & 9 & 22.5 & 13 & 32.5 & 13 & 32.5 \\
S10 & 5 & 12.5 & 14 & 35.0 & 6 & 15.0 & 15 & 37.5 \\
S11 & 4 & 10.0 & 14 & 35.0 & 12 & 30.0 & 10 & 25.0 \\
S12 & 5 & 12.5 & 7 & 17.5 & 19 & 47.5 & 9 & 22.5 \\
Total & $\mathbf{6 9}$ & & $\mathbf{1 2 4}$ & & $\mathbf{1 2 5}$ & & $\mathbf{1 6 2}$ & \\
\hline
\end{tabular}

As displayed in Table 1, different impolite complaint strategies have been used by Iranian EFL learners of the study to realize the complaint strategies in all situations. According to the above table, the most frequent strategy across all situations is Positive Impoliteness, registering 162 impolite complaints. The second most frequent impolite complaint strategy was Negative Impoliteness, registering 125 strategies. A total of 124 sarcasms were used by Iranian EFL leaners of the study to realize impolite complaints, nominating Sarcasm as the third most frequent strategy. And, as it is displayed in the above table, Bald on Record registered 69 cases as the fourth most frequent strategy.

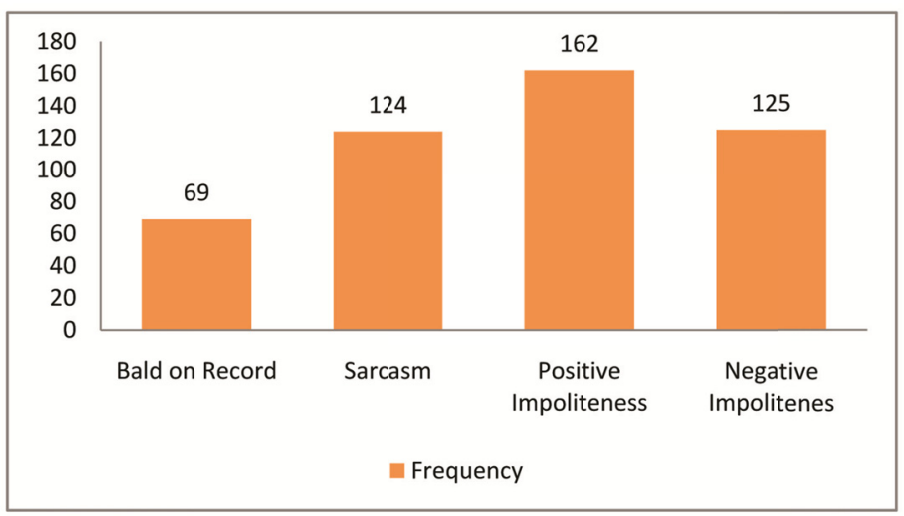

Figure 1. Total frequency of impolite complaints across all situations by Iranian EFL learners

As displayed in Figure 1, the frequency use of impolite complaint strategies employed by Iranian EFL students is different across different situations. However, the first research question was looking for significant differences among impolite complaint strategies. Since the frequency of impolite complaint strategies, namely Bald on Record, Sarcasm, Positive Impoliteness, and Negative Impoliteness were categorical data, and the first research question was looking for significant differences in the frequency of one variable (impolite complaint) in one group (Iranian EFL learners), the statistical procedure Chi-square Goodness-of-fit was used to check whether the difference among the frequency use of impolite complaint strategies is significant or not.

Table 2. Type of impolite complaints by EFL learners

\begin{tabular}{llll}
\hline & Observed N & Expected N & Residual \\
\hline Bald on Record & 69 & 120.0 & -51.0 \\
Sarcasm & 124 & 120.0 & 4.0 \\
Negative & 125 & 120.0 & 5.0 \\
Positive & 162 & 120.0 & 42.0 \\
Total & 480 & & \\
\hline
\end{tabular}

It is worth mentioning that the chi-square goodness-of-fit test is a single-sample nonparametric test. It is used to determine whether the distribution of cases (e.g., impolite complaints) in a single categorical variable follows a known or hypothesized distribution. 
Table 3. Chi-square goodness-of-fit for impolite complaints by EFL learners

\begin{tabular}{ll}
\hline & Type of Strategy \\
\hline Chi-Square & $36.717^{\mathrm{a}}$ \\
$\mathrm{df}$ & 3 \\
Asymp. Sig. & .000 \\
\hline a. 0 cells $(.0 \%)$ have expected frequencies less than 5. The minimum expected cell \\
frequency is 120.0.
\end{tabular}

As it can be seen in Table 3, the difference among the frequency use of impolite complaint strategies employed by Iranian EFL students was statistically significant $X^{2}(3)=36.717, p \leq 0.05$. According to the above table the significance value (0.000) corresponding to this comparison was less than the $p$ value (.05). The conclusion to be drawn from these analyses would be that there is a significant difference among the frequency use of impolite complaint strategies employed by Iranian EFL students.

\subsection{Research Question Two}

The second research question of the study was posed to check whether social distance affects the use of impolite complaint strategies realized by Iranian EFL learners. To answer the question, the distribution of impolite complaints in high social distance and low social distance situations was calculated. As it was mentioned earlier, the situations in the questionnaire of the study were designed to test the effect of social distance as an independent variable. Accordingly, situations 1 and 2 were parallel situations that were only different in terms of social distance status; so were situations 3 and 4, 5 and 6,7 and 8,9 and 10,11 and 12. To serve the purpose of study systematically, the odd situations (situations $1,3,5,7,9$, and 11) included low social distance status and even situations (situations $2,4,6,8,10$, and 12) included high social distance status.

Table 4. Frequency and percentages of impolite complaints in low social distance situations

\begin{tabular}{lllllllll}
\hline \multirow{2}{*}{ Situations } & \multicolumn{7}{c}{ Bald on Record } & \multicolumn{7}{c}{ Sarcasm } & \multicolumn{2}{c}{$\begin{array}{c}\text { Strategies } \\
\text { Negative Impoliteness }\end{array}$} & Positive Impoliteness \\
\cline { 2 - 9 } & F & P (\%) & F & P (\%) & F & P (\%) & F & P (\%) \\
\hline S1 & 7 & 17.5 & 17 & 42.5 & 6 & 15.0 & 10 & 25.0 \\
S3 & 12 & 30.0 & 8 & 20.0 & 6 & 15.0 & 14 & 35.0 \\
S5 & 11 & 27.5 & 14 & 35.0 & 7 & 17.5 & 8 & 20.0 \\
S7 & 1 & 2.5 & 11 & 27.5 & 9 & 22.5 & 19 & 47.5 \\
S9 & 5 & 12.5 & 9 & 22.5 & 13 & 32.5 & 13 & 32.5 \\
S11 & 4 & 10.0 & 14 & 35.0 & 12 & 30.0 & 10 & 25.0 \\
Total & $\mathbf{4 0}$ & & $\mathbf{7 3}$ & & $\mathbf{5 3}$ & & $\mathbf{6 4}$ & \\
\hline
\end{tabular}

As it is displayed in Table 4, the most frequent impolite complaint strategy used by Iranian EFL learners of the study in low social distance situations were sarcastic complaints, registering 73 cases. In low social distance situations, positive impolite complaint was used as the second most frequent impolite complaint by Iranian EFL participants, recording 64 cases. The third impolite complaint strategy used by participants of the study was negative impoliteness, registering 53 cases. And, a total number of 40 bald on record impolite complaints were used as the least frequent strategy in low social distance situations.

Table 5. Frequency and percentages of impolite complaints in high social distance situations

\begin{tabular}{lllllllll}
\hline \multirow{2}{*}{ Situations } & \multicolumn{7}{c}{ Bald on Record } & \multicolumn{7}{c}{ Sarcasm } & \multicolumn{2}{c}{$\begin{array}{c}\text { Strategies } \\
\text { Negative Impoliteness }\end{array}$} & Positive Impoliteness \\
\cline { 2 - 9 } & F & P (\%) & F & P (\%) & F & P (\%) & F & P (\%) \\
\hline S2 & 7 & 17.5 & 2 & 5.0 & 21 & 52.5 & 10 & 25.0 \\
S4 & 7 & 17.5 & 5 & 12.5 & 12 & 30.0 & 16 & 40.0 \\
S6 & 1 & 2.5 & 12 & 30.0 & 13 & 32.5 & 14 & 35.0 \\
S8 & 4 & 10.0 & 11 & 27.5 & 1 & 2.5 & 24 & 60.0 \\
S10 & 5 & 12.5 & 14 & 35.0 & 6 & 15.0 & 15 & 37.5 \\
S12 & 5 & 12.5 & 7 & 17.5 & 19 & 47.5 & 9 & 22.5 \\
Total & $\mathbf{2 9}$ & & $\mathbf{5 1}$ & & $\mathbf{7 2}$ & & $\mathbf{8 8}$ & \\
\hline
\end{tabular}


As for high social distance situations, Table 5 shows that the most frequent strategy preferred by Iranian EFL learners of the study was positive impolite complaint, recording 88 cases. In contrary to low social distance situations in which the second most frequent strategy was sarcasm, in high social distance situations the second most frequent strategy used by participants of the study was negative impolite complaints, registering 72 cases. As the third strategy, the Iranian EFL participants of the study used 51 sarcasms to realize impolite complaints in high social distance situations. And, a total of 29 bald on record impolite complaint strategies were used as the least frequent strategy by the participants of the study.

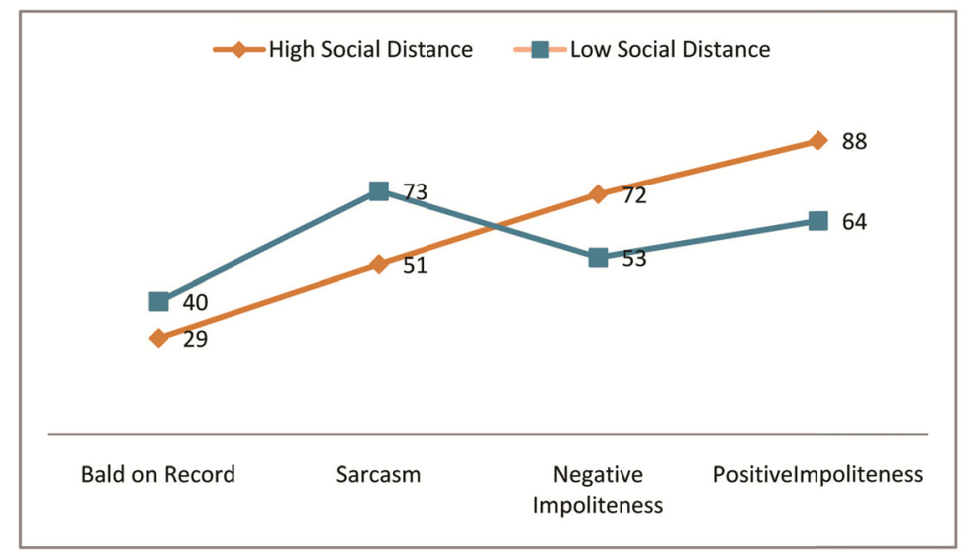

Figure 2. Frequency of impolite complaint strategies in high and low social distance situations by Iranian EFL learners

According to Figure 2, the status of social distance in situations affects not only the frequency use of impolite complaint strategies but also the preference of Iranian EFL learners on the choice of impolite complaint strategy, because the distribution of impolite complaint strategy type and frequency does not follow a similar pattern in high and low social distance situations. As it is displayed above, compared to low social distance situations in which 73 sarcasms were used, positive impolite complaints use in high social distance situations reached 88 cases as the most frequent strategy. Moreover, in contrary to high social distance situations in which negative impolite complaints (72 cases) were the second most frequent strategy, in low social distance situations positive impolite complaints ( 73 cases) was preferred by the Iranian EFL learners as the second favorable impolite complaint. Another difference underpinned between high and low social distance situations was the frequency bald on record impolite complaints. The participants of the study used 29 cases of bald on record impolite complaints in high social distance situations; however, in low social distance situations there were 40 cases of bald on record impolite complaints. The following cross-tabulation strategy type in high and low social distance situations is helpful in comparison of situations.

Table 6. Social distance status by strategy type cross-tabulation for Iranians

\begin{tabular}{|c|c|c|c|c|c|c|c|}
\hline & & & $\begin{array}{l}\text { Strategy } \\
\text { Bald on } \\
\text { Record }\end{array}$ & Sarcasm & $\begin{array}{l}\text { Negative } \\
\text { Impoliteness }\end{array}$ & $\begin{array}{l}\text { Positive } \\
\text { Impoliteness }\end{array}$ & Total \\
\hline Social Distance & Low & Count & 40 & 73 & 53 & 64 & 220 \\
\hline \multirow[t]{7}{*}{ Status } & & $\%$ within Social Distance Status & $18.2 \%$ & $28.6 \%$ & $24.1 \%$ & $29.1 \%$ & $100.0 \%$ \\
\hline & & $\%$ within Strategy & $58.0 \%$ & $55.3 \%$ & $42.4 \%$ & $42.1 \%$ & $47.8 \%$ \\
\hline & & $\%$ of Total & $8.7 \%$ & $13.7 \%$ & $11.5 \%$ & $13.9 \%$ & $47.8 \%$ \\
\hline & High & Count & 29 & 51 & 72 & 88 & 240 \\
\hline & & $\%$ within Social Distance Status & $12.1 \%$ & $21.3 \%$ & $30.0 \%$ & $36.7 \%$ & $100.0 \%$ \\
\hline & & $\%$ within Strategy & $42.0 \%$ & $44.7 \%$ & $57.6 \%$ & $57.9 \%$ & $52.2 \%$ \\
\hline & & $\%$ of Total & $6.3 \%$ & $11.1 \%$ & $15.7 \%$ & $19.1 \%$ & $52.2 \%$ \\
\hline \multirow[t]{4}{*}{ Total } & & Count & 69 & 124 & 125 & 162 & 460 \\
\hline & & $\%$ within Social Distance Status & $15.0 \%$ & $24.8 \%$ & $27.2 \%$ & $33.0 \%$ & $100.0 \%$ \\
\hline & & $\%$ within Strategy & $100.0 \%$ & $100.0 \%$ & $100.0 \%$ & $100.0 \%$ & $100.0 \%$ \\
\hline & & $\%$ of Total & $15.0 \%$ & $24.8 \%$ & $27.2 \%$ & $33.0 \%$ & $100.0 \%$ \\
\hline
\end{tabular}


In order to check whether the differences in the frequency use of impolite complaint strategies between high and low social distance situations was statistically significant, Chi-square statistical procedure was run.

Table 7. Chi-square for the difference of complaint frequencies by Iranians in high and low social distance situations

\begin{tabular}{llll}
\hline & Value & df & Asymptotic Significance (2-sided) \\
\hline Pearson Chi-Square & $8.841^{\mathrm{a}}$ & 3 & .031 \\
Likelihood Ratio & 8.861 & 3 & .031 \\
Linear-by-Linear Association & 7.470 & 1 & .006 \\
N of Valid Cases & 460 & & \\
a. 0 cells $(0.0 \%)$ have expected count less than 5. The minimum expected count is 33.00. \\
\hline
\end{tabular}

As it can be seen in Table 7, the difference among the frequency use of impolite complaint strategies employed by Iranian EFL students in high and low social distance situations was statistically significant $\chi^{2}(3)=8.841$, $p \leq 0.05$. According to the above table, the significance value (0.031) corresponding to this comparison was less than the $\mathrm{p}$ value (.05). The results imply that social distance significantly affect the use of impolite complaint strategies realized by Iranian EFL learners.

\subsection{Research Question Three}

Another objective of the study was the use of impolite complaint strategies among native English speakers. The third research question of the study "is there any significant difference among impolite complaint strategies realized by native English speakers?" addressed this objective. To answer the third research question the frequency use of impolite complaint strategies realized by native English speakers were calculated and tabulated as follows.

Table 8. Frequency and percentages of impolite complaints across all situations for natives

\begin{tabular}{|c|c|c|c|c|c|c|c|c|}
\hline \multirow{3}{*}{ Situations } & \multicolumn{8}{|c|}{ Strategies } \\
\hline & \multicolumn{2}{|c|}{ Bald on Record } & \multicolumn{2}{|c|}{ Sarcasm } & \multicolumn{2}{|c|}{ Negative Impoliteness } & \multicolumn{2}{|c|}{ Positive Impoliteness } \\
\hline & $\mathrm{F}$ & $\mathrm{P}(\%)$ & $\mathrm{F}$ & $\mathrm{P}(\%)$ & $\mathrm{F}$ & $\mathrm{P}(\%)$ & $\mathrm{F}$ & $\mathrm{P}(\%)$ \\
\hline S1 & 5 & 25.0 & 4 & 20.0 & 3 & 15.0 & 8 & 40.0 \\
\hline S2 & 2 & 10.0 & 3 & 15.0 & 6 & 30.0 & 9 & 45.0 \\
\hline $\mathrm{S} 3$ & 3 & 15.0 & 3 & 15.0 & 7 & 35.0 & 7 & 35.0 \\
\hline S4 & 10 & 50.0 & 3 & 15.0 & 6 & 30.0 & 1 & 5.0 \\
\hline S5 & 5 & 25.0 & 5 & 25.0 & 3 & 15.0 & 7 & 35.0 \\
\hline S6 & 1 & 5.0 & 1 & 5.0 & 10 & 50.0 & 8 & 40.0 \\
\hline S7 & 1 & 5.0 & 5 & 25.0 & 0 & 0.0 & 14 & 70.0 \\
\hline S8 & 3 & 15.0 & 1 & 5.0 & 5 & 25.0 & 11 & 55.0 \\
\hline S9 & 7 & 35.0 & 3 & 15.0 & 8 & 40.0 & 2 & 10.0 \\
\hline $\mathrm{S} 10$ & 3 & 15.0 & 11 & 55.0 & 4 & 20.0 & 2 & 10.0 \\
\hline S11 & 3 & 15.0 & 6 & 30.0 & 8 & 40.0 & 3 & 15.0 \\
\hline $\mathrm{S} 12$ & 4 & 20.0 & 5 & 25.0 & 3 & 15.0 & 8 & 40.0 \\
\hline Total & 47 & & 50 & & 63 & & 80 & \\
\hline
\end{tabular}

According to Table 8, the distribution of impolite complaints, namely Bald on Record, Sarcasm, Negative Impoliteness, and Positive Impoliteness was not equal across situations. As it is displayed above, the first priority was given to Positive Impoliteness by native English speakers to realize complaints impolitely, recording 80 cases of the strategy. Following Positive Impolite complaints, native English speakers realized 63 Negative Impolite complaints as the second most frequent strategy. Sarcasm was realized 50 times as the third most frequent impolite complaint strategy by native English speakers. And, the least frequent impolite complaint realized by native English speakers of the study was Bald on record, registering 47 cases. 


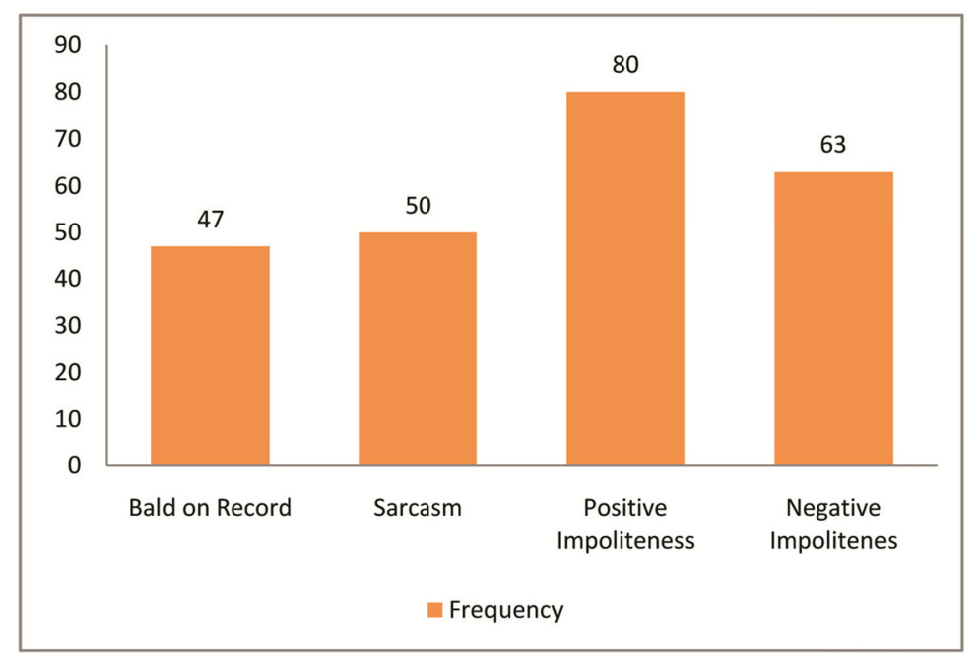

Figure 3. Total frequency of impolite complaints across all situations by natives

The first research question was looking for significant differences among impolite complaint strategies realized by native English speakers. According to Figure 3, the frequency use of impolite complaint strategies realized was different across different situations. Accordingly, the statistical procedure Chi-square Goodness-of-fit was used to check whether the differences among the frequency use of impolite complaint strategies was significant or not.

Table 9. Type of impolite complaints by natives

\begin{tabular}{llll}
\hline & Observed N & Expected N & Residual \\
\hline Bald on Record & 47 & 58.8 & -11.8 \\
Sarcasm & 50 & 58.8 & -8.8 \\
Negative & 63 & 58.8 & 4.3 \\
Positive & 80 & 58.8 & 16.3 \\
Total & 235 & & \\
\hline
\end{tabular}

Since Chi-square Goodness-of-fit is calculated based on observed frequency of categorical variables, namely Bald on Record, Sarcasm, Negative Impoliteness, and Positive Impoliteness, and the expected frequency of the variables are also required to obtain the difference between observed and expected frequency (Residual), Table 9 provided the required parameters for calculating Chi-square Goodness-of-fit.

Table 10. Chi-square goodness-of-fit for impolite complaints by natives

\begin{tabular}{ll}
\hline & Type of Strategy \\
\hline Chi-Square & $8.455^{\text {a }}$ \\
df & 3 \\
Asymp. Sig. & .037 \\
\hline a. 0 cells $(.0 \%)$ have expected frequencies less than 5. The minimum \\
expected cell frequency is 58.8.
\end{tabular}

As displayed in Table 10, the difference among the frequency use of impolite complaint strategies realized by native English speakers was statistically significant $X^{2}(3)=8.455, p \leq 0.05$. According to the above table, the significance value (0.037) corresponding to this comparison was less than the $p$ value $(.05)$. The statistical analysis led the researcher to deduce that there is a significant difference among the frequency use of impolite complaint strategies realized by native English speakers.

\subsection{Research Question Four}

Another concern of the present study was to check whether social distance as one of the contextual variables 
influences the choice of impolite complaint strategies or not. To this end, the third research question of the study was posed as follows "does social distance significantly affect the use of impolite complaint strategies realized by native English speakers?"

In order to find out whether native English speakers were sensitive to the social distance between the speakers and addressee in an interaction and whether the social distance between the speaker and addressee affected the choice of impolite complaints realized by native English speakers, the frequency use of impolite complaints were calculated in low social distance situations as well as high social distance situations.

Table 11. Frequency and percentages of impolite complaints in low social distance situations for natives

\begin{tabular}{lllllllll}
\hline \multirow{2}{*}{ Situations } & \multicolumn{2}{l}{$\begin{array}{l}\text { Strategies } \\
\text { Bald on Record }\end{array}$} & \multicolumn{2}{l}{ Sarcasm } & \multicolumn{2}{c}{ Negative Impoliteness } & \multicolumn{2}{c}{ Positive Impoliteness } \\
\cline { 2 - 9 } & F & P (\%) & F & P (\%) & F & P (\%) & F & P (\%) \\
\hline S1 & 5 & 25.0 & 4 & 20.0 & 3 & 15.0 & 8 & 40.0 \\
S3 & 3 & 15.0 & 3 & 15.0 & 7 & 35.0 & 7 & 35.0 \\
S5 & 5 & 25.0 & 5 & 25.0 & 3 & 15.0 & 7 & 35.0 \\
S7 & 1 & 5.0 & 5 & 25.0 & 0 & 0.0 & 14 & 70.0 \\
S9 & 7 & 35.0 & 3 & 15.0 & 8 & 40.0 & 2 & 10.0 \\
S11 & 3 & 15.0 & 6 & 30.0 & 8 & 40.0 & 3 & 15.0 \\
Total & $\mathbf{2 4}$ & & $\mathbf{2 6}$ & & $\mathbf{2 9}$ & & $\mathbf{4 1}$ & \\
\hline
\end{tabular}

As displayed in Table 11, the most frequent impolite complaint strategy used by native English speakers of the study in low social distance situations was positive impolite complaints, registering 41 cases. In low social distance situations, Negative Impoliteness was used as the second most frequent impolite complaint by native English speakers, recording 29 cases. The third impolite complaint strategy used by participants of the study was Sarcasm, registering 26 cases. And a total number of 24 Bald on Record impolite complaints were used as the least frequent strategy in low social distance situations.

Table 12. Frequency and percentages of impolite complaints in high social distance situations for natives

\begin{tabular}{lllllllll}
\hline \multirow{2}{*}{ Situations } & \multicolumn{2}{l}{$\begin{array}{l}\text { Strategies } \\
\text { Bald on Record }\end{array}$} & \multicolumn{2}{l}{ Sarcasm } & \multicolumn{2}{l}{ Negative Impoliteness } & \multicolumn{2}{l}{ Positive Impoliteness } \\
& F & P (\%) & F & P (\%) & F & P (\%) & F & P (\%) \\
\hline S2 & 2 & 10.0 & 3 & 15.0 & 6 & 30.0 & 9 & 45.0 \\
S4 & 10 & 50.0 & 3 & 15.0 & 6 & 30.0 & 1 & 5.0 \\
S6 & 1 & 5.0 & 1 & 5.0 & 10 & 50.0 & 8 & 40.0 \\
S8 & 3 & 15.0 & 1 & 5.0 & 5 & 25.0 & 11 & 55.0 \\
S10 & 3 & 15.0 & 11 & 55.0 & 4 & 20.0 & 2 & 10.0 \\
S12 & 4 & 20.0 & 5 & 25.0 & 3 & 15.0 & 8 & 40.0 \\
Total & $\mathbf{2 3}$ & & $\mathbf{2 4}$ & & $\mathbf{3 4}$ & & $\mathbf{3 9}$ & \\
\hline
\end{tabular}

As for high social distance situations, Table 12 shows that the most frequent strategy preferred by native English speakers of the study was positive impolite complaints, recording 39 cases. In line with low social distance situations in which the second most frequent strategy was Negative Impolite complaints, in high social distance situations the second most frequent strategy used by native English speakers of the study was Negative Impolite complaints too, registering 34 cases. As the third strategy, the native English speakers of the study used 24 sarcasms to realize impolite complaints in high social distance situations. And, a total 23 Bald on Record impolite complaint strategies were used as least frequent strategy by the native English speakers of the study. 


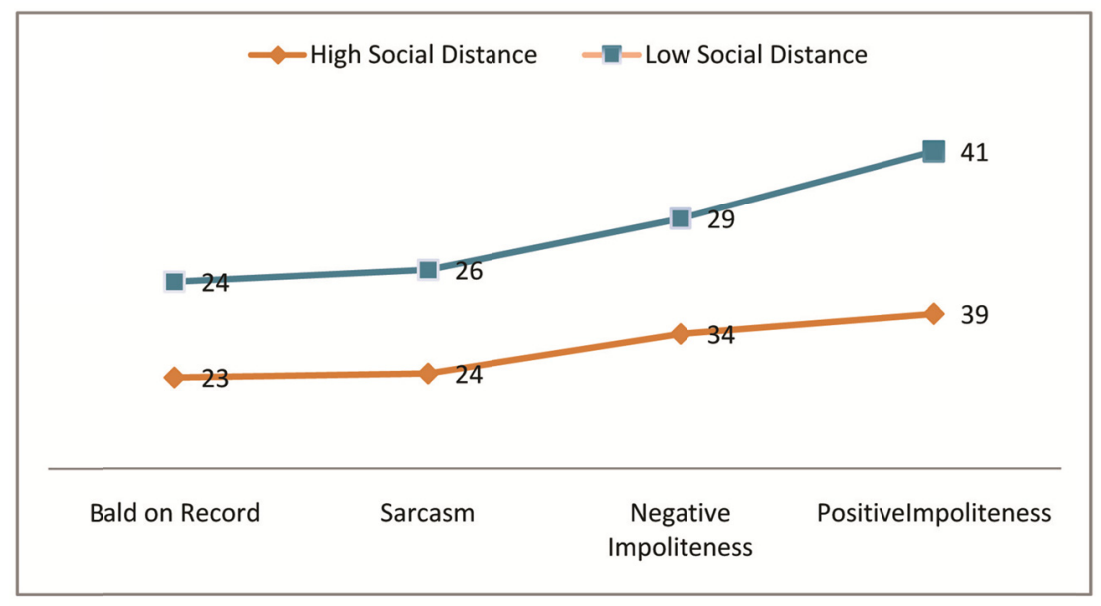

Figure 4. Frequency of impolite complaint strategies in high and low social distance situations by natives

Because the frequency distribution of impolite complaint strategies in low and high social distance situations follows a similar pattern, the status of social distance in low and high social distance situations seem to have the same effect on the choice of impolite complaint strategies among Native English speakers. As Figure 4 displays, in line with low social distance situations in which Positive Impolite complaints were used as the most frequent strategy, Positive Impolite complaints in high social distance situations were used as the most frequent strategy too. Moreover, like high social distance situations in which Negative Impolite complaints were the second most frequent strategy, in low social distance situations Negative Impolite complaints were again preferred by the English native speakers as the second favorable impolite complaints. Another similarity underpinned between high and low social distance situations was the frequency of sarcastic impolite complaints. The English native speakers of the study used Sarcasm as the third most frequent impolite complaints in both low and high social distance situations. And, the last type of impolite complaint realized by the English native speakers in both low and high social distance situations was Bald on Record impolite complaints. The following cross-tabulation strategy type in high and low social distance situations is helpful in comparison of situations.

Table 13. Social distance status by strategy type cross-tabulation for natives

\begin{tabular}{|c|c|c|c|c|c|c|c|}
\hline & & & $\begin{array}{l}\text { Strategy } \\
\text { Bald on } \\
\text { Record } \\
\end{array}$ & Sarcasm & $\begin{array}{l}\text { Negative } \\
\text { Impoliteness }\end{array}$ & $\begin{array}{l}\text { Positive } \\
\text { Impoliteness } \\
\end{array}$ & Total \\
\hline Social Distance & Low & Count & 24 & 26 & 29 & 41 & 120 \\
\hline \multirow[t]{7}{*}{ Status } & & $\%$ within Social Distance Status & $20.0 \%$ & $21.7 \%$ & $24.2 \%$ & $34.2 \%$ & $100.0 \%$ \\
\hline & & $\%$ within Strategy & $51.1 \%$ & $52.0 \%$ & $46.0 \%$ & $51.2 \%$ & $50.0 \%$ \\
\hline & & $\%$ of Total & $10.0 \%$ & $10.8 \%$ & $12.1 \%$ & $17.1 \%$ & $50.0 \%$ \\
\hline & High & Count & 23 & 24 & 34 & 39 & 120 \\
\hline & & $\%$ within Social Distance Status & $19.2 \%$ & $20.0 \%$ & $28.3 \%$ & $32.5 \%$ & $100.0 \%$ \\
\hline & & $\%$ within Strategy & $48.9 \%$ & $48.0 \%$ & $54.0 \%$ & $48.8 \%$ & $50.0 \%$ \\
\hline & & $\%$ of Total & $9.6 \%$ & $10.0 \%$ & $14.2 \%$ & $16.3 \%$ & $50.0 \%$ \\
\hline \multirow[t]{4}{*}{ Total } & & Count & 47 & 50 & 63 & 80 & 240 \\
\hline & & $\%$ within Social Distance Status & $19.6 \%$ & $20.8 \%$ & $26.3 \%$ & $33.3 \%$ & $100.0 \%$ \\
\hline & & $\%$ within Strategy & $100.0 \%$ & $100.0 \%$ & $100.0 \%$ & $100.0 \%$ & $100.0 \%$ \\
\hline & & $\%$ of Total & $19.6 \%$ & $20.8 \%$ & $26.3 \%$ & $33.3 \%$ & $100.0 \%$ \\
\hline
\end{tabular}

Although the frequency use of impolite compliant strategies by English native speakers in low and high social distance situations was different, inferential statistics was required to make sure the differences in the frequency use of impolite complaint strategies between high and low social distance situations was statistically significant. Therefore, Chi-square statistical procedure was run. 
Table 14. Chi-square for the difference of complaint frequencies by natives in high and low social distance situations

\begin{tabular}{llll}
\hline & Value & df & Asymptotic Significance (2-sided) \\
\hline Pearson Chi-Square & $.548^{\mathrm{a}}$ & 3 & .908 \\
Likelihood Ratio & .549 & 3 & .908 \\
Linear-by-Linear Association & .013 & 1 & .908 \\
N of Valid Cases & 240 & & \\
a. 0 cells $(0.0 \%)$ have expected count less than 5. The minimum expected count is 23.50. \\
\hline
\end{tabular}

As it can be seen in Table 14, the difference among the frequency use of impolite complaint strategies realized by English native speakers in high and low social distance situations was not statistically significant $\chi^{2}(3)=.548$, $p \leq 0.05$. According to the above table the significance value $(0.908)$ corresponding to this comparison was greater than the $\mathrm{p}$ value (.05). The results imply that social distance does not have a significant effect on the use of impolite complaint strategies realized by English native speakers.

\subsection{Research Question Five}

As a general objective, after exploring the use of impolite complaint strategies among the two groups of participants of the study, namely Iranian EFL learners and English native speakers, the study was also interested in the comparison the two groups of participants of the study. Accordingly, the fifth research question of the study was posed as follows: Is there any significant difference between Iranian EFL learners and English native speakers in the frequency use of impolite complaint strategies?

To answer the question, the frequency use of impolite compliant strategies of every group was calculated as displayed in the following figure.

\section{- Iranian EFL Learners $\quad$ English Native Speakers}



Figure 5. Frequency of impolite complaint strategies by Iranian EFL learners and English native speakers

As Figure 5 displays, the most frequent impolite complaint strategy among the participants of the both groups is positive impoliteness. Moreover, the participants of the both groups preferred negative impoliteness as the second most favorable impolite complaint strategy. The two groups both opted for sarcasm as the third choice for the realization of impolite complaints. And, the last choice for the realization of impolite complaint was Bald on Record among the participants of the two groups. 
Table 15 . Nationality by strategy type cross-tabulation

\begin{tabular}{|c|c|c|c|c|c|c|c|}
\hline & & & $\begin{array}{l}\text { Strategy } \\
\text { Bald on } \\
\text { Record } \\
\end{array}$ & Sarcasm & $\begin{array}{l}\text { Negative } \\
\text { Impoliteness }\end{array}$ & $\begin{array}{l}\text { Positive } \\
\text { Impoliteness }\end{array}$ & Total \\
\hline \multirow[t]{8}{*}{ Nationality } & Iranian EFL & Count & 69 & 124 & 125 & 162 & 480 \\
\hline & Learners & $\%$ within Nationality & $14.4 \%$ & $25.8 \%$ & $26.0 \%$ & $33.8 \%$ & $100.0 \%$ \\
\hline & & $\%$ within Strategy & $59.5 \%$ & $71.3 \%$ & $66.5 \%$ & $66.9 \%$ & $66.7 \%$ \\
\hline & & $\%$ of Total & $9.6 \%$ & $17.2 \%$ & $17.4 \%$ & $22.5 \%$ & $66.7 \%$ \\
\hline & English & Count & 47 & 50 & 63 & 80 & 240 \\
\hline & Native & $\%$ within Nationality & $19.6 \%$ & $20.8 \%$ & $26.3 \%$ & $33.3 \%$ & $100.0 \%$ \\
\hline & Speakers & $\%$ within Strategy & $40.5 \%$ & $28.7 \%$ & $33.5 \%$ & $33.1 \%$ & $33.3 \%$ \\
\hline & & $\%$ of Total & $6.5 \%$ & $6.9 \%$ & $8.8 \%$ & $11.1 \%$ & $33.3 \%$ \\
\hline \multirow[t]{4}{*}{ Total } & & Count & 116 & 174 & 188 & 242 & 720 \\
\hline & & $\%$ within Nationality & $16.1 \%$ & $24.2 \%$ & $26.1 \%$ & $33.6 \%$ & $100.0 \%$ \\
\hline & & $\%$ within Strategy & $100.0 \%$ & $100.0 \%$ & $100.0 \%$ & $100.0 \%$ & $100.0 \%$ \\
\hline & & $\%$ of Total & $16.1 \%$ & $24.2 \%$ & $26.1 \%$ & $33.6 \%$ & $100.0 \%$ \\
\hline
\end{tabular}

According to above cross-tabulation of strategy type by groups of participants, the distribution of impolite complaints follows the a similar pattern among the participants of the both groups; that is to say, Positive Impoliteness followed by Negative Impoliteness, Sarcasm, and Bald on Record as the most frequent strategies respectively. However, the frequency use of impolite complaint strategies was not equal among the participants of the two groups.

Although the frequency use of impolite compliant strategies by English native speakers and Iranian EFL learners was different, inferential statistics were required to make sure the differences in the frequency use of impolite complaint strategies between the two groups was statistically significant. Therefore, Chi-square statistical procedure was run.

Table 16. Chi-square for the difference of complaint frequencies by natives and Iranian EFL learners

\begin{tabular}{llll}
\hline & Value & df & Asymptotic Significance (2-sided) \\
\hline Pearson Chi-Square & $4.360^{\mathrm{a}}$ & 3 & .225 \\
Likelihood Ratio & 4.320 & 3 & .229 \\
Linear-by-Linear Association & .465 & 1 & .496 \\
N of Valid Cases & 720 & & \\
\hline
\end{tabular}

a. 0 cells $(0.0 \%)$ have expected count less than 5 . The minimum expected count is 38.67 .

According to Table 16, the difference among the frequency use of impolite complaint strategies realized by English native speakers and Iranian EFL learners was not statistically significant $\chi^{2}(3)=4.360, p \leq 0.05$. According to the above table, the significance value (0.225) corresponding to this comparison was greater than the p value (.05). The results imply that there is not any significant difference between Iranian EFL learners and English native speakers in the frequency use of impolite complaint strategies.

\subsection{Research Question Six}

As stated in chapter three one of the instruments of data collection was a structured interview. The interview was designed in this study to identify the reason of impolite complaint strategies used by Iranian EFL students as the last research question of the study was "Why do Iranian EFL learners opt for a given impolite complaint strategy?"

For the interview the researcher selected 20 participants of the study after they had filled in the questionnaire and posed a single question to them. The question was "why did you choose ...... strategy in situation.....?". After recording the participants' responses, the researcher transcribed them carefully to classify the participants" responses to interview question.

Out of twenty participants, eleven interviewees stated that "they prefer to be more sarcastic to addressees to whom they had low social distance"; that is to say, one of the reasons for opting for sarcasm as an impolite complaint strategy among Iranian EFL learners was the degree to which the participants were familiar with the addressee. This was in line with the results of the second question in which it was found that social distance significantly affect the use of impolite complaint strategies realized by Iranian EFL learners. In answer to the 
second research question it was also revealed that the most frequent impolite complaint strategy in low social distance was sarcasm.

Three of the interviewees had a complete different opinion and said that "they would rather be more direct to friends and relatives and more sarcastic with strangers because she would never see strangers again".

Another reason referred to by participants of the study as a reason for choosing impolite complaints was the compliance by the addressee. Eighteen out of twenty interviewees stated that "friendly complaints have a stronger potentiality to be accepted by addressees and that is why they selected positive impolite complaint strategies". The participants' responses were consistent with the general patterns of the frequency use of impolite complaint strategies by Iranian EFL learners. In answer to research question one, it was revealed that the most frequent impolite complaint strategy among Iranian EFL learners was positive impoliteness.

Moreover, it was highlighted by fifteen participants of the study that "social distance is an effective factor in choosing the impolite complaint strategy". This finding was consistent with the results of the second question in which it was found that social distance significantly affect the use of impolite complaint strategies realized by Iranian EFL learners.

\section{Discussion}

The summary of the results elaborated in the previous section is restated here: based on the statistical analysis of the results, both descriptive and inferential, it was revealed that a) there were significant differences among the impolite strategies used by Iranian EFL learners, b) social distance affected the use of impolite complaint strategies realized by Iranian EFL learners, c) there were significant differences among the impolite strategies used by native English speakers, d) social distance did not significantly affect the use of impolite complaint strategies realized by native English speakers, and e) there was no significant difference between Iranian EFL learners and native English speakers in the frequency use of impolite complaint strategies.

\subsection{Impolite Complaint Strategies by Iranian EFL Learners}

The first research hypothesis stated that there is no significant difference among impolite complaint strategies realized by Iranian EFL learners. The results of the analyses rejected the hypothesis because there were significant differences among the impolite strategies realized by Iranian EFL learners.

Allami and Montazeri (2012) examined the strategies that are used by Iranian EFL learners for expressing complaints. The data were collected through a 24-item English Discourse Completion Task (DCT) to which 40 male and female EFL learners were asked to provide short responses. The responses were coded based on micro (17 categories) and macro (7 categories) coding scales. Learners' confidence in their own pragmatic ability was assessed through self-assessment scores. The results of their study revealed that most participants preferred to express their complaint directly.

These results are in line with the findings of current since the most common strategy used by Iranian participants was positive impoliteness which is a kind of expressing the opinion directly. Although Iranian participants avoided being very impolite, they tried expressing their complaints directly.

Ghahraman and Nakhle (2013) conducted a study to make a contrastive cross-cultural pragmatic analysis between native Canadian speakers and Iranian EFL learners with regard to the speech act of complaint. The participants of the study were 20 Canadian university students majoring in different fields and 20 among Iranian EFL learners, respectively. The results of the study revealed that different complaint speech acts were used by Iranian participants and there were significant different differences among them.

These findings are in line with the results of the current study since in both studies Iranian participants used different strategies for expressing their complaints and there were significant differences among them. It can be noted that different people have different realizations of complaint speech acts.

The preference of Iranian EFL learners for different impolite complaint strategies could be influenced by contextual variables, including social distance and power relations, in which the language is used. According to Brown and Levinson (1987) the social distance between the interlocutors is one of the measures that is taken to account by the interlocutors when performing a speech act in relation to politeness/impoliteness. The Iranian EFL learners of the study and have opted for different impolite complaints that best fits the social distance of the situation in which they complained.

\subsection{Social Distance and Use of Impolite Complaint Strategies by Iranian EFL Learners}

The second research hypothesis stated that social distance does not significantly affect the use of impolite complaint strategies realized by Iranian EFL learners. The results of the analyses revealed that there were 
significant differences among the strategies used by Iranian participants based on social distance. Therefore, this research hypothesis was rejected.

Ahmadian and Eslami-Rasekh (2011) explored the strategies used by Iranians Americans when they want to express their reprimands. Twenty five Americans and 35 Iranians participated in this study in four situations. Interviews were carried out to find out the participants' perceptions regarding reprimanding strategies. The study suggested that there are indeed differences between these two cultures regarding this speech act. They also concluded that social distance is the important factor in the way the Iranians reprimand while it was not the case for Americans.

These results are in line with the findings of the present study because the results of the current study revealed that social distance is an important factor in realizing the complaint speech acts by Iranian participants. It was found that there was a significant difference in realization of the complaint speech acts by Iranian participants based on different social distances.

The results of the current study confirm the findings of the study that was done by Ghahraman and Nakhle (2013) who stated that social power is an important that causes differential use of complaint utterances by Iranian EFL learners.

The results once again highlight the impact of contextual variables such as social distance and social power, as explained in politeness theory by Brown and Levinson (1987). The Iranian EFL learners of the study seem to be sensitive to the social distance between them and their interlocutors when they are going to express their complaints impolitely.

\subsection{Impolite Complaint Strategies by Native English Speakers}

The third research hypothesis stated that there is no significant difference among impolite complaint strategies realized by English native speakers. The results revealed that there were significant differences among impolite complaint strategies realized by English native speakers. Therefore, this research hypothesis was rejected.

Zhang (2001) used a Discourse Completion Task to elicit complaints in 8 hypothetical situations from 94 subjects, 32 Chinese longer-term residents with an average length of 3.2 years' residence in the U.S., 30 Chinese short-term residents who had stayed in the U.S for an average of 0.5 year, and 32 Americans. The findings showed significant differences among the strategies that were used by American participants.

These findings are parallel with the results of the current study since in both studies the American participants used different complaint strategies and there were significant differences among the strategies that were used by them. The results of the present study are also in line with the findings of the study that was done by Ghahraman and Nakhle (2013). They stated that various complaint speech acts were used by Canadians and there were significant differences among them.

\subsection{Social Distance and Use of Impolite Complaint Strategies by Native English Speakers}

The fourth research hypothesis states that social distance does not significantly affect the use of impolite complaint strategies realized by native English speakers. The results of the analyses revealed that there were significant differences among the strategies used by native participants based on social distance. Therefore, this research hypothesis was rejected.

Zhang (2001) stated that social distance significantly affected the performance of complaining of American and Chinese participants in his study. Therefore, these two studies are parallel with each other since they both stated that social distance significantly influence the realization of complain speech by native English speakers. These results are also in line with the findings of the study done by Ghahraman and Nakhle (2013). They stated that social distance significantly affects the speech acts that are used by native English speakers in expressing complaints.

On the other hand, Ahmadian and Eslami-Rasekh (2011) stated that social distance significantly affected the complaint strategies used by Iranian participants but not by American participants in their study. Therefore, the results of their study are not parallel with the results of the current study because in the present study social distance was an important factor in realizing the complaint speech acts by the American participants.

According to Brown and Levinson's (1987) theory of politeness, the impact of social distance as one of the contextual variables could be one the reason based on which different impolite strategies are used. 


\subsection{Difference between Iranian EFL Learners and Native English Speakers in the Frequency Use of Impolite Complaint Strategies}

To test this research hypothesis all impoliteness strategies that were used by Iranian EFL learners and native speakers of English in all 12 situations of the study were scrutinized and they were all counted and tabulated. In addition, inferential analyses were conducted to examine the possible differences between Iranian EFL learners and native speakers of English in using impoliteness strategies used in different situations. The most common impoliteness strategy that was used by Iranian and native speakers was positive impoliteness and the least common strategy was bald-on-record. It can be noted that both Iranian EFL learners and native speakers of English had similar preferences for impoliteness strategies used when complaining. That is to say, both groups intended to express their complaints directly.

Tajeddin et al. (2014) investigated native English speakers and EFL learners' perception of impoliteness. Seventy-five native speakers and 177 EFL learners were administered a discourse completion task for the speech act of apology accompanied by responses violating politeness by various degrees. Participants were asked to assess the degree of impoliteness embedded in each response and to write down their assessment comments. Content analysis of respondents' comments indicated that both groups mentioned similar impoliteness criteria. However, the analysis of frequency counts displayed significant differences between the two groups in their degree of preference for each impoliteness criterion.

These findings are not in line with the results of the current study because in this study the differences were not significant in most situations. Although there were differences between Iranian EFL learners and native speakers of English in this study in using impoliteness strategies, the most and least common strategies that were employed by these two groups of participants were the same and the differences of using impoliteness strategies were not significant between Iranian EFL learners and native speakers of English.

Kim (2008) investigated the pragmatic proficiency of complaint in certain situations. A discourse completion test (DCT) was administered to 35 Korean college learners enrolled in regular English courses. The results showed that complaints are too direct in the EFL cultural context as produced by Korean speakers of English; sometimes these subjects' complaints are actually realized through direct criticism. Most of students fail to demonstrate the high level of pragmatic competence, and they are not able to carry out strategies appropriate to the native speakers.

These results are not in line with the findings of the present study since Iranian EFL learners of this study preferred to express their complaints more indirectly than Korean EFL learners did. It can be concluded that the complaint speech act strategies are more similar between English and Persian in comparison between Korean and English, since Persian and English both belong to the same language family which is Indo-European languages.

Deveci (2010) investigated the complaint speech used by Turkish EFL learners in two different situations: speaking to a commiserating teacher and speaking to a contradicting teacher. Four kinds of data sources were used to collect data in the classroom: twenty native English speakers' role-plays, twenty-five Turkish native speakers' role-plays, and forty students' role-plays. The subjects' complaint speech act sets were a coding scheme borrowed from a previously conducted study by Murphy and Neu (1996). The findings revealed that when speaking to the commiserating teacher, students made both positive and negative transfer in using "demand". The students speaking to the contradicting teacher made positive transfer in the components "explanation of purpose", "complaint", and "justification". The component "demand" was subject to negative transfer.

These results are in line with the findings of the current study since Turkish EFL learners like Iranian EFL learners preferred to be more indirect in low social distance and more direct in high social distance for expressing complaints. It can also be concluded that the behavior of the interlocutor can be an important factor on using the kind of the complaint speech act by the speaker.

Based on the results of the current study and comparison of the results with previous studies, it is deduced that language speakers are inspired by the culture dominating the community in which speakers interact. Accordingly, differences and similarities might be observed between the speech acts used by speakers coming from different linguistics backgrounds. However, the similarities between Iranian EFL learners and native English speakers could be due to the fact that although both groups used the same language in this study, it was observed that both groups' interactions are constrained by similar socio-cultural norms. 


\section{Conclusions}

Undoubtedly, impoliteness is an important aspect of language and it has been studied by so many researchers (Bousfield, 2008; Culpeper, 1996, 2005; Dynel, 2013; Furman, 2011; Keykhayee, 2013; Laitinen, 2011). Although most studies and teaching methods focused on politeness (Khatib \& Lotfi, 2015), impoliteness attracted the attention of researchers (Lowe, 2009) as well, since acquiring good competency and fluency is almost impossible without being familiar with impolite language (Tanck, 2002). Therefore, an attempt was made in this study to investigate the impoliteness strategies that are used by Iranian EFL learners and native speakers of English in complaint speech acts and to figure out the differences between Iranian EFL learners and native speakers of English in using the impoliteness strategies in relation to social distance.

After conducting the study and doing the necessary statistical analyses, it was found that all impoliteness strategies were used by both Iranian EFL learners and native speakers of English. The most common strategy that was used by both groups was positive impoliteness and the least common one was bald-on-record. In addition, the differences among the strategies used by each group were significant. It can be concluded that both groups did not want to appear so impolite but they tried to express their complaints directly the way that their interlocutors understand they are unsatisfied with the situation.

The results of the social distance analyses revealed that social distance is influential in the realization of impolite complaints as native speakers preferred to use different impolite complaints in low and high social distance situations. Moreover, Iranian EFL learners seem to be sensitive to the degree to which they are familiar with the addressee (social distance) when complaining. Iranian EFL learners used sarcasm in low social distance situations to perform a complaint. As sarcasm is a brand of humor (Loewen, 2016) it may help to express the speakers' dissatisfaction not that bitterly. Accordingly, in low social distance, Iranians prefer to use sarcastic language to expressing their complaints with a sense of humor. Native speakers avoid expressing their complaints indirectly and they would like to be direct through a positive impolite complaint. Therefore, social distance seems to act to some extent similarly in Persian and English culture as far as impolite complaint realization is concerned.

\section{Implications}

As previously mentioned, impoliteness is an important feature of language and acquiring fluency in language is almost impossible without having enough familiarity with it (Tanck, 2002). Impolite expressions are used to some extent by all native speakers of all languages; thus, without having the knowledge of it, EFL learners are unable to understand native speakers precisely, and it hinders their learning process. Therefore, this study would inform Iranian EFL learners of the importance of impoliteness, and recommend them improve their general proficiency in this regard more effectively.

This study would also help Iranian EFL instructors with teaching impoliteness to their students properly; and it suggests Iranian EFL instructors familiarize EFL learners with impolite complaints with regards to such contextual variables as social distance. It would also help them to teach the cultural differences between Iranians and native speakers of English to their students and enable them to use these expressions in these two contexts properly. This study also would help curriculum designers in Iran to put this function of language in their curricula and make Iranian EFL learners a have better understanding of authentic conversations by native speakers and improve their general English knowledge more quickly and effectively. This study, it is hoped, to help Iranian EFL learners become familiar with the impolite strategies that are used by native speakers of English for expressing complaints and gain more native-like competency.

\section{Limitations}

In conducting the present study, some limitations were confronted which can potentially restrict the generalizability of the results. First, the Iranian participants of the study were restricted to upper-intermediate EFL learners, whereas examining other levels of proficiency might produce different results. Second, the number of participants, especially native speakers was very limited; by increasing the number of participants, more comprehensive results can be acquired. Third, the study was limited to complaint speech act; other speech acts can be put under investigation. Fourth, the number of situations was limited to only 12 situations; by using increasing the number of situations, more inclusive results can be obtained.

\section{References}

Ahmadian, M. J., \& Eslami-Rasekh, A. (2011). A Comparative Study of Reprimand Strategies: Evidence from Iranian and American Speech Communities. The Social Sciences, 6(1), 1-7. https://doi.org/10.3923/sscience.2011.1.7 
Ahn, R. C. (2005). Five measures of interlanguage pragmatics in KFL (Korean as foreign language) learners. University of Hawaii at Manoa.

Allami, H., \& Montazeri, M. (2012). Iranian EFL Learners' Compliment Responses. System: An International Journal of Educational Technology and Applied Linguistics, 40(4), 466-482. https://doi.org/10.1016/j.system.2012.10.010

Allan, D. (2004). Oxford Placement Test 2: Test Pack. Oxford: Oxford University Press.

Austin, J. L. (1962). How to do things with words. Oxford: Clarendon Press.

Babcock, P., \& Gove, P. B. (1993). Webster's Third New International Dictionary of the English Language, Unabridged: Since 1847 the Ultimate Word Authority for Schools, Libraries, Courts, Homes, and Offices. Merriam-Webster.

Bahrani, T., \& Sim, T. (2012). Informal Language Learning Setting: Technology or Social Interaction?. Turkish Online Journal of Educational Technology, 11(2), 142-149.

Bousfield, D. (2008). Impoliteness in interaction. Amsterdam: John Benjamins Publishing Company. https://doi.org/10.1075/pbns.167

Bousfield, D., \& Locher, M. (2008). Impoliteness in language: Studies on its interplay with power in theory and practice. Berlin: Mouton de Gruyter.

Corder, S. P. (1987). Error analysis and interlanguage (Vol. 112). Oxford: Oxford University Press.

Culpeper, J. (1996). Towards an anatomy of impoliteness. Journal of Pragmatics, 25, 349-367. https://doi.org/10.1016/0378-2166(95)00014-3

Culpeper, J. (2005). Impoliteness and entertainment in the television quiz show: The Weakest Link. Journal of Politeness Research. Language, Behaviour, Culture, 1(1), 37-52. https://doi.org/10.1515/jplr.2005.1.1.35

Culpeper, J., Bousfield, D., \& Wichmann, A. (2003). Impoliteness revisited: with special reference to dynamic and prosodic aspects. Journal of Pragmatics, 35(10-11), 1545-1579. https://doi.org/10.1016/S0378-2166(02)00118-2

Deveci, T. (2010). The Use of Complaints in the Inter-Language of Turkish EFL Learners. Colombian Applied Linguistics Journal, 12(2), 25-42.

Dynel, M. (2013). On impoliteness and drama discourse: an interview with Jonathan Culpeper. International Review of Pragmatics, 5, 163-188. https://doi.org/10.1163/18773109-13050107

Fatmasari, D. R. (2015). Complaint Strategy of EFL Learners from the Perspective of Discourse Completion Task (A Case Study of Students of English Department Universitas Brawijaya). University of Brawijaya.

Furman, M. (2011). Impoliteness and mock-impoliteness in Dom 2. Ohio State University.

Ghahraman, V., \& Nakhle, M. (2013). A Contrastive Study on the Complaint Behavior among Canadian Native. The Iranian EFL Journal, 20(21.67), 313.

Jianda, L. (2007). Developing a pragmatics test for Chinese EFL learners. Language Testing, 24(3), 391-415. https://doi.org/10.1177/0265532207077206

Karakayali, N. (2009). Social Distance and Affective Orientations. Sociological Forum (Vol. 24, pp. 538-562). New York: Wiley Online Library. https://doi.org/10.1111/j.1573-7861.2009.01119.x

Keykhayee, M. (2013). The Relationship of the Type and Number of Impoliteness Strategies Employed by Sistani Students with Addressee's Power and Gender. International Journal of Basic Sciences \& Applied, 2(4), 352-361.

Khatib, M., \& Lotfi, K. (2015). Impoliteness and Power: An Interlanguage Pragmatic Approach to the Use of Impolite Patterns in Terms of Power. Journal of English Language Teaching and Learning, 7(15), 43-67.

Kim, D. Y. (2008). A Study of Complaint Strategies for EFL College Learners. Contemporary English education, 9(2), 58-70.

Laitinen, M. (2011). Breaking the rules of communication: Verbal and nonverbal impoliteness in the American Hospital Drama House MD. University of Jyväskylä.

Lewis, A. (2003). WordWeb dictionary. Princeton University.

Locher, M. A., \& Bousfield, D. (2008). Introduction: Impoliteness and power in language. Language Power and 
Social Process, 21, 1.

Loewen, S. C. (2016). Psychology of Sarcasm-Dealing With Sarcastic People. Retrieved from http://www.healthguidance.org/entry/15845/1/Psychology-of-Sarcasm--Dealing-With-Sarcastic-People.html

Lowe, C. (2009). Impoliteness in Language: Studies on its Interplay with Power in Theory and Practice. In D. Bousfield \& M. A. Locher (Eds.), Journal of Pragmatics, 41(9), 1865-1869. Berlin: Mouton de Gruyter. https://doi.org/10.1016/j.pragma.2009.05.001

Mugford, G. (2008). How rude! Teaching impoliteness in the second-language classroom. ELT Journal, 62(4), 375-384. https://doi.org/10.1093/elt/ccm066

Rezaei, S. (2010). Developing a multiple-choice discourse completion test of interlanguage pragmatics for Iranian EFL learners. ILI Language Teaching Journal, 6(1-2), 1-17.

Richards, J. C., \& Schmidt, R. (2010). Longman dictionary of language teaching and applied linguistics. New York: Routledge.

Roever, C. (2006). Validation of a web-based test of ESL pragmalinguistics. Language Testing, 23(2), 229-256. https://doi.org/10.1191/02655322061t329oa

Rogers, A. (2004). Looking again at non-formal and informal education-towards a new paradigm. The Encyclopaedia of Informal Education.

Setoguchi, E. (2008). Multiple-choice Discourse Completion Tasks in Japanese English Language Assessment.

Stevenson, A., \& Waite, M. (2011). Concise Oxford English Dictionary: Book \& CD-ROM Set. Oxford University Press.

Tajeddin, Z., Alemi, M., \& Razzaghi, S. (2014). Cross-cultural Perceptions of Impoliteness by Native English Speakers and EFL Learners: The Case of Apology Speech Act. Journal of Intercultural Communication Research, 43(4), 304-326. https://doi.org/10.1080/17475759.2014.967279

Tanck, S. (2002). Speech act sets of refusal and complaint: A comparison of native and non-native English speakers' production.

Trosborg, A. (1994). Translation studies: Some recent developments. Hermes, Journal of Linguistics, 12, 9-28.

Zamanian, M., Karimi, M. G., \& Kashkouli, S. M. (2015). (Im) politeness Strategies in Top Notch and Iran Language Institute Book Series. Journal of Applied Linguistics and Language Research, 2(2), 33-38.

Zhang, D. (2001). The speech act of complaining: a cross-cultural comparative study of Chinese and American English speakers. Iowa State University.

\section{Copyrights}

Copyright for this article is retained by the author(s), with first publication rights granted to the journal.

This is an open-access article distributed under the terms and conditions of the Creative Commons Attribution license (http://creativecommons.org/licenses/by/4.0/). 